\title{
Trophic transfer of Fe, Zn and Am from marine bacteria to a planktonic ciliate
}

\author{
Catherine Vogel $^{*}$, Nicholas S. Fisher \\ School of Marine and Atmospheric Sciences, Stony Brook University, Stony Brook, New York 11794-5000, USA
}

\begin{abstract}
Marine bacteria may serve as an enriched source of essential and non-essential metals for animals that eat them. We evaluated this trophic transfer by measuring the accumulation of $\mathrm{Fe}, \mathrm{Zn}$ and Am by planktonic ciliates (Uronema sp.) following the ingestion of radiolabeled heterotrophic bacteria (Vibrio natriegens) in laboratory experiments. V. natriegens cells were allowed to accumulate ${ }^{55} \mathrm{Fe},{ }^{65} \mathrm{Zn}$ and ${ }^{241} \mathrm{Am}$ from seawater for $5 \mathrm{~d}$ and were subsequently fed to the ciliates. Uptake and depuration of the metals was monitored in the ciliates over time. Measured assimilation efficiencies were $79 \%$ for $\mathrm{Fe}$, $29 \%$ for $\mathrm{Zn}$ and $24 \%$ for Am; corresponding efflux rates were $0.1 \mathrm{~d}^{-1}$ for Fe, $0.9 \mathrm{~d}^{-1}$ for $\mathrm{Zn}$ and $0.7 \mathrm{~d}^{-1}$ for Am. These results suggest that bacteria present an alternate source to phytoplankton for some metals (especially $\mathrm{Fe}$ ) to be introduced into metazoan food webs.
\end{abstract}

KEY WORDS: Trophic transfer $\cdot$ Ciliated protozoa $\cdot$ Heterotrophic bacteria $\cdot$ Metals $\cdot$ Metal cycling

\section{INTRODUCTION}

Trophic transfer studies in the marine environment most often rely on phytoplankton to represent the base of the food web under examination. The ability of microalgal cells to bioconcentrate metals of varying properties (Fisher 1986) and to transfer them to the organisms grazing on phytoplankton has been documented (Fisher et al. 1983b, 1984, Reinfelder \& Fisher 1991). Few studies have examined the transfer of metals from bacterial cells to their consumers in aquatic environments (Chase \& Price 1997, Maranger et al. 1998, Barbeau et al. 2001), particularly involving ciliates (Berk \& Colwell 1981, Lores et al. 1999). Half of the particulate organic carbon in the world's oceans is contained in heterotrophic bacteria (Cho \& Azam 1988, Fuhrman et al. 1989), illustrating their potential importance in influencing the geochemical cycling of metals and nutrients in general. The accumulation of diverse metals by bacterial cells from ambient seawater has been quantified experimentally (C. Vogel \& N. S. Fisher unpubl.). Here we examined the extent to which bacterially associated metals can be transferred to protozoans that graze upon them.
Elements that are accumulated by bacteria become incorporated into the microbial loop, a highly efficient system at regenerating nutrients (Azam et al. 1983). However, the microbial loop is not a system that exists in isolation, but is also connected to the 'traditional' phytoplankton-based metazoan food chain. Therefore, bacterially bound metals may eventually enter into the larger oceanic food web. One of these links is represented by planktonic ciliates, many of which are bacterivores (Porter et al. 1985, Sherr \& Sherr 1987) and ubiquitous in most aquatic systems (Beers \& Stewart 1969, Fenchel 1986). Through excretion, protozoans can play a significant role in the regeneration of nutrients in the aquatic environment (Johannes 1965, Gast \& Horstmann 1983, Porter et al. 1985), and ciliates in particular are suitable prey items for zooplankton such as copepods (Berk et al. 1977, Rieper 1985). Also, they may be a better dietary source for some copepods than phytoplankton based on egg development and hatching success (Heinle et al. 1977). Further, copepods assimilate certain metals (e.g. Zn) more efficiently from ciliates than from algal cells (Twining \& Fisher 2004).

Different types of metals are accumulated by bacteria and some metals are bound mostly to external cell 
surfaces, while others may also move across the membranes and accumulate inside the cells. The assimilation of a metal from algal food by herbivores is tightly correlated with that metal's cytoplasmic distribution in the food (Reinfelder \& Fisher 1991, 1994, Hutchins et al. 1995). A similar pattern was observed in the trophic transfer of $\mathrm{Ag}$ and $\mathrm{Pb}$ to the estuarine ciliate Fabrea salina feeding on the naked prymnesiophyte Isochrysis galbana (Fisher et al. 1995). In the present study we have chosen 3 different metals ( $\mathrm{Fe}, \mathrm{Zn}$ and americium [Am]) to investigate the trophic transfer to planktonic ciliates feeding on heterotrophic bacteria. $\mathrm{Zn}$ and particularly Fe are particle-reactive and essential trace metals that are known to be transported into bacterial cells (Tortell et al. 1996, Keung et al. 2008) and could therefore be expected to be assimilated to a relatively large extent by the ciliates. In contrast, Am is a particle-reactive element with no biological function. However, there is interest in this element from a radiological protection perspective (IAEA 2004) and its geochemical behavior is much like that of the lanthanides and some other actinides that are also particlereactive, namely, +3 valence metals. As with algal cells (Fisher et al. 1983a), Am is expected to remain attached to the cell surfaces of bacteria and be less assimilated by the ciliates.

\section{MATERIALS AND METHODS}

Experiments were conducted in filtered natural seawater that was collected in trace-metal clean fashion from surface waters $8 \mathrm{~km}$ offshore from Southampton, New York. Cultures of the heterotrophic marine bacterium Vibrio natriegens strain Pwh3a (provided by G. Taylor) were maintained on marine agar slants (1 1 seawater, $5 \mathrm{~g}$ bacto peptone, $1 \mathrm{~g}$ yeast extract) at $4^{\circ} \mathrm{C}$ and were subcultured periodically. In preparation for experiments $V$. natriegens was cultured in $10 \%$ marine broth $(1 \mathrm{l}$ seawater, $0.5 \mathrm{~g}$ bacto peptone, $0.1 \mathrm{~g}$ yeast extract) for $4 \mathrm{~d}$ before an inoculum was centrifuged at $1400 \times g$ for $10 \mathrm{~min}$ and rinsed with sterile $0.2 \mu \mathrm{m}$ filtered seawater before resuspending the cells.

Cultures of the planktonic ciliate Uronema sp. (provided by A. Hartz and isolated from Pacific coastal seawater in Oregon) were maintained at $17^{\circ} \mathrm{C}$ in sterile filtered seawater that was supplemented with a sterile rice grain and Vibrio natriegens, and were subcultured periodically. Before each experiment, batches of the ciliates were transferred to fresh seawater containing an inoculum of rinsed $V$. natriegens, but no rice grain, for $4 \mathrm{~d}$. Preliminary experiments established that $V$. natriegens serves as an adequate food source for the ciliates. Uronema sp. are smaller celled, bacterivorous ciliates in the order Scuticociliatida that are abundant in coastal regions (Sherr \& Sherr 1987). The average cell volume of the ciliates was $559 \mathrm{\mu m}^{3}$, which was based on the shape of a prolate ellipsoid and was calculated from length and width measurements obtained by light microscopy of 50 ind. cells.

For the trophic transfer experiments, rinsed Vibrio natriegens cells $\left(10^{6}\right.$ cells $\left.\mathrm{ml}^{-1}\right)$ were suspended in $800 \mathrm{ml}$ of $0.2 \mu \mathrm{m}$ filtered seawater to which radioisotope had been added $12 \mathrm{~h}$ before the bacterial inoculation. Radioisotopes used in these experiments included ${ }^{55} \mathrm{Fe}$ (half-life $\left[t_{1 / 2}\right]=996 \mathrm{~d}_{\text {; }}$ dissolved in $0.5 \mathrm{~N} \mathrm{HCl}$ ) in the form of $\mathrm{FeCl}_{3}$ from NEN/Perkin Elmer Life Sciences, ${ }^{65} \mathrm{Zn}\left(t_{1 / 2}=245 \mathrm{~d}\right.$; dissolved in $\left.0.1 \mathrm{~N} \mathrm{HCl}\right)$, as $\mathrm{ZnCl}_{2}$ from Brookhaven National Laboratory and ${ }^{241} \mathrm{Am}\left(t_{1 / 2}=\right.$ $433 \mathrm{yr}$; dissolved in $\left.3 \mathrm{~N} \mathrm{HNO}_{3}\right)$ as $\mathrm{Am}\left(\mathrm{NO}_{3}\right)_{3}$ from Amersham. The trophic transfer of $\mathrm{Fe}$ was tested separately, whereas Zn and Am were tested simultaneously. The concentrations of the radioisotopes were $0.9 \mathrm{nmol} \mathrm{l}^{-1}(19.98 \mathrm{kBq})$ for ${ }^{55} \mathrm{Fe}, 1.94 \mathrm{nmol} \mathrm{l} \mathrm{l}^{-1}$ (39.96 kBq) for ${ }^{65} \mathrm{Zn}$, and $1.14 \mathrm{nmol}^{-1}(23.68 \mathrm{kBq})$ for ${ }^{241} \mathrm{Am}$. Each volume of seawater that received radioisotopes also first received a small amount (microliter quantities) of $0.5 \mathrm{~N} \mathrm{NaOH}$ to offset the small amount (microliter quantitites) of dilute acid added along with the radioisotopes.

To determine the accumulation of the isotopes in the ciliates from bacterial food, the bacteria were exposed to radioisotopes for $5 \mathrm{~d}$, after which they were collected on $0.2 \mu \mathrm{m}$ Nuclepore polycarbonate membranes, rinsed with sterile seawater and resuspended in triplicate flasks, each containing $250 \mathrm{ml}$ seawater and approximately 2 to $4 \times 10^{3}$ ciliate cells $\mathrm{ml}^{-1}$. A separate set of flasks containing $250 \mathrm{ml}$ seawater without ciliates also received an inoculum of radiolabeled Vibrio natriegens to determine the loss via desorption of the radioisotopes from bacterial cells to the water. Cellular and dissolved samples were taken periodically over a period of $4 \mathrm{~h}$ for Fe and $15 \mathrm{~h}$ for Am and $\mathrm{Zn}$. At each sample time, a $1 \mathrm{ml}$ unfiltered sample was taken to determine the total activity of the metal in the aqueous and the particulate phases, and a $10 \mathrm{ml}$ sample was collected on $5.0 \mu \mathrm{m}$ Nuclepore polycarbonate membranes (and rinsed 2 times with $5 \mathrm{ml}$ of filtered seawater) to determine the radioactivity associated with the ciliates. In previous studies (C. Vogel \& N. S. Fisher unpubl.) we found no evidence of bacterial clumping that would be caught on these filters. A $10 \mathrm{ml}$ sample was also filtered $(0.2 \mu \mathrm{m})$ and rinsed with $10 \mathrm{ml}$ seawater to determine the activity of the metals associated with $V$. natriegens in the flasks containing only the bacterial cells.

To measure metal retention in ciliates, radioactive Uronema were removed from their radioactive bacte- 
ria food and fed non-radioactive bacteria to purge any undigested bacteria and unassimilated metal. Thus, at the end of the radioactive feeding the radiolabeled ciliates that had been feeding on radiolabeled Vibrio natriegens were gravity filtered $(5.0 \mu \mathrm{m})$, rinsed with seawater and resuspended into 3 flasks each containing $160 \mathrm{ml}$ of seawater and $5 \times 10^{6}$ cells ml $^{-1}$ of unlabeled $V$. natriegens food. Filtered $(10 \mathrm{ml})$ and unfiltered $(1 \mathrm{ml})$ samples were taken periodically from these flasks to determine the loss of metals from the ciliates during $28 \mathrm{~h}$ in the Fe experiment and $15 \mathrm{~h}$ in the Am and $\mathrm{Zn}$ experiment.

In addition, the contents of the flasks that contained only radiolabeled Vibrio natriegens were collected on a $0.2 \mu \mathrm{m}$ polycarbonate filter, and the resulting radiolabeled filtrate was used to measure the accumulation of desorbed metals by unlabeled Uronema (added at 0.95 to $1.40 \times 10^{3} \mathrm{cells} \mathrm{ml}^{-1}$ ) from the dissolved phase.

Radioactive samples were measured using a 1282 Compugamma counter (LKB Wallac) equipped with a $\mathrm{NaI}(\mathrm{Tl})$ well detector for the gamma emitting radioisotopes ${ }^{65} \mathrm{Zn}$ and ${ }^{241} \mathrm{Am}$. Gamma emissions of ${ }^{65} \mathrm{Zn}$ were measured at $1115 \mathrm{keV}$, and at $59.5 \mathrm{keV}$ for ${ }^{241} \mathrm{Am}$. Samples containing the beta emitter ${ }^{55} \mathrm{Fe}$ were measured in a Tri-Carb 2100 TR liquid scintillation analyzer (Packard), taking a quench curve into consideration. In general, samples were counted so that propagated counting errors were $<5 \%$.

At various times throughout the experiments, samples were taken to determine the cell densities of ciliates and bacteria. Vibrio natriegens samples were filtered onto $0.2 \mu \mathrm{m}$ black polycarbonate filter membranes for this purpose, and $5.0 \mu \mathrm{m}$ filters were used for Uronema sp. Both types of cells were fixed with $2 \%$ final volume borate-buffered formalin and counted by 4'6-diamidino-2-phenylidole (DAPI) staining (Sherr et al. 2001) and epifluorescence microscopy using a DMB IRB inverted microscope (Leica) in all experiments.

For Vibrio natriegens, concentration factors for each metal were determined by dividing the radioactivity of each radioisotope in the cells by the radioactivity in the ambient seawater at the time of equilibrium with respect to metal partitioning between dissolved and particulate phases. Concentration factors were calculated on a volume/ volume basis, assessed by dividing the radioactivity $\mu^{-3}$ of bacterial cells by the

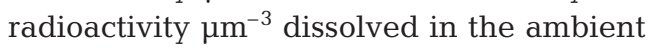
seawater (Fisher et al. 1983b). The cell volume for the ciliates was calculated based on the shape of a prolate ellipsoid, with the length and width dimensions measured by means of light microscopy; the cell volume for the bacterial cells was calculated based on the shape of a rod.
Assimilation efficiencies (AE) of the metals in Uronema sp. were calculated based on the filtered and unfiltered samples taken during the depuration phase of the experiments. Depuration data were plotted showing the percentage of each metal retained by the ciliates upon resuspension into unlabeled seawater. Assimilation efficiencies were obtained by fitting an exponential regression to the depuration data from $2 \mathrm{~h}$ after the beginning of the depuration period to the last sample time. The assimilation efficiency is represented by the $y$-intercept of this curve and the slope of the curve represents the efflux rate constant $\left(k_{\mathrm{e}}\right)$ (Wang \& Fisher 1999). This method of determining a metal's assimilation efficiency is appropriate for organisms for which the time required for digestion is difficult to measure. Typically, marine invertebrates, including zooplankton, display a biphasic depuration pattern with an initial rapid loss representing egestion of unassimilated material followed by a slower loss that represents loss of assimilated metal due to metabolic processes. We chose the $2 \mathrm{~h}$ time point as the beginning of the second phase of depuration because $2 \mathrm{~h}$ is a sufficiently long enough time for egestion to take place in Uronema sp. (Sherr et al. 1988). Essentially, the $y$ intercept of the slowly exchanging pool is equal to (the ingested metal - the egested metal)/(ingested metal).

\section{RESULTS}

The initial $5 \mathrm{~d}$ exposure period of Vibrio natriegens to the different radioisotopes resulted in volume concentration factors of $1.5 \times 10^{6}$ for ${ }^{55} \mathrm{Fe}, 8.4 \times 10^{4}$ for ${ }^{65} \mathrm{Zn}$ and $4.1 \times 10^{4}$ for ${ }^{241} \mathrm{Am}$ on the bacterial cells (Table 1). The radiolabeled $V$. natriegens retained most of the Fe that they had accumulated during the initial $5 \mathrm{~d}$ labeling period. After $4 \mathrm{~h}$ of resuspension in seawater without ciliates, the cells still retained approximately $88 \%$ of the Fe (Fig. 1). V. natriegens cells lost Zn to the surrounding water relatively rapidly over the course of $1 \mathrm{~h}$, after which approximately $50 \%$ of this metal remained bound to the bacteria. The bacterial cells lost $\mathrm{Zn}$ at a slower rate from this point onward and

Table 1. Calculated volume concentration factors (VCF) in Vibrio natriegens during the initial $5 \mathrm{~d}$ labeling period, assimilation efficiencies (AE, in percent $\pm \mathrm{SE}$ ) of the 3 metals in Uronema sp., daily efflux rates $\left(k_{\mathrm{e}}\right)$ of the metals from the ciliates, and concentrations of the 3 metals $\mu \mathrm{m}^{-3}$ in each of the 2 study organisms at the end of the metal uptake phase (bacterial cells and ciliates)

\begin{tabular}{|cccccc|}
\hline & $\begin{array}{c}\text { Bacterial } \\
\text { VCF }\end{array}$ & $\begin{array}{c}\text { Ciliate AE } \\
(\%)\end{array}$ & $\begin{array}{c}\text { Ciliate } \\
k_{\mathrm{e}}\left(\mathrm{d}^{-1}\right)\end{array}$ & $\begin{array}{c}{\text { amol } \mu \mathrm{m}^{-3}}_{\text {bacteria }} \\
\text { amol } \mu \mathrm{m}^{-3} \\
\text { ciliate }\end{array}$ \\
\hline $\mathrm{Fe}$ & $1.50 \times 10^{6}$ & $79 \pm 3$ & 0.1 & 0.55 & 0.17 \\
$\mathrm{Zn}$ & $8.43 \times 10^{4}$ & $29 \pm 2$ & 0.9 & 0.14 & 0.07 \\
$\mathrm{Am}$ & $4.14 \times 10^{4}$ & $24 \pm 1$ & 0.7 & 0.04 & 0.02 \\
\hline
\end{tabular}




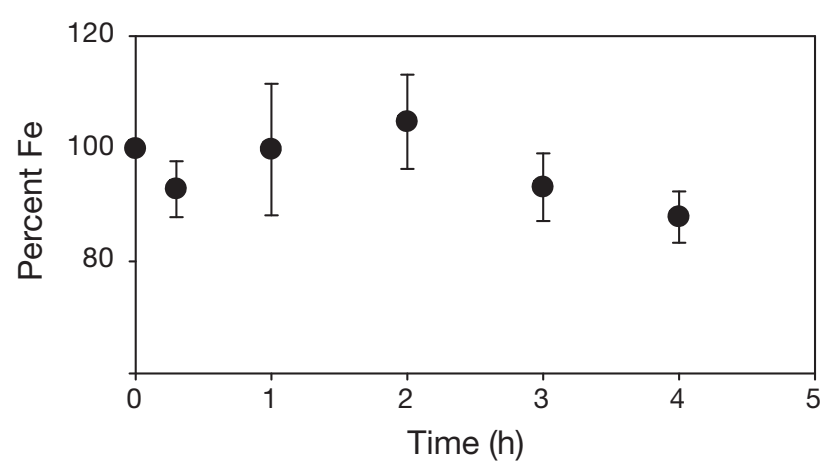

Fig. 1. Percentage of ${ }^{55} \mathrm{Fe}$ retained by Vibrio natriegens over time after resuspending the cells into sterile filtered, unlabeled seawater. Data are means $( \pm \mathrm{SE}$ ) of 3 replicates

retained $30 \%$ of this metal by the final sample time. Am was also lost relatively rapidly from the bacteria over the first $1 \mathrm{~h}$, at which time $40 \%$ of it remained associated with bacterial cells. After $1 \mathrm{~h}$, Am also desorbed from the cells at a slower rate, until $23 \%$ of Am remained cell-bound at the final sample time (Fig. 2).

Once the radiolabeled bacteria were available for consumption by the ciliates, approximately $65 \%$ of the Fe bound to bacterial cells was transferred to the ciliates due to ingestion of the bacteria (Fig. 3). Of the ${ }^{55} \mathrm{Fe}$ found in the ciliates, up to $15 \%$ may have been taken up from the aqueous phase resulting from desorption from bacteria and the remainder from ingestion of the radiolabeled bacteria. The initial dietary uptake

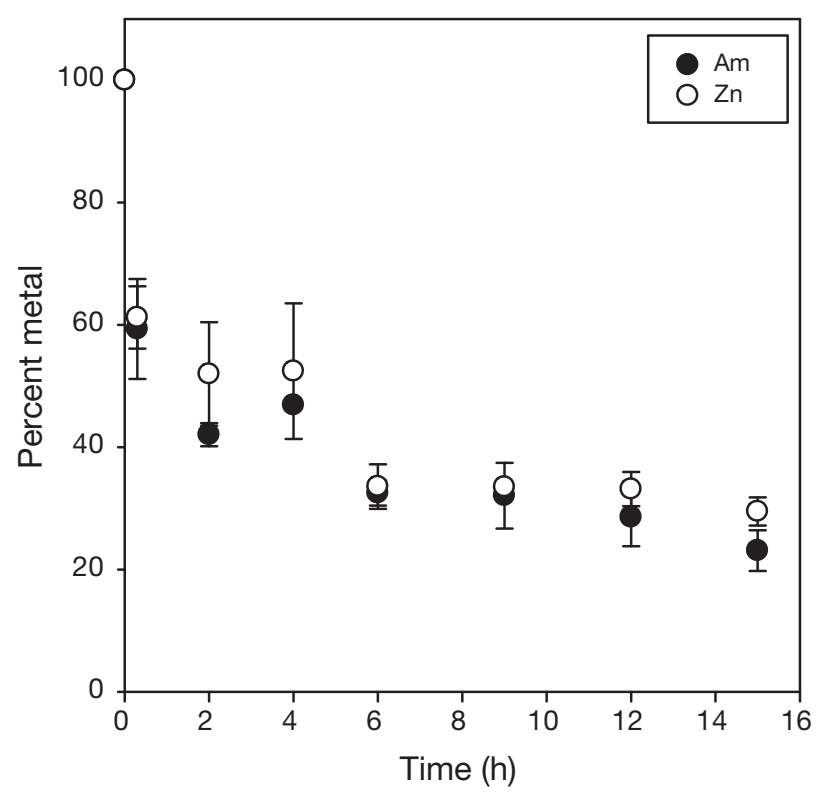

Fig. 2. Percentage of ${ }^{241} \mathrm{Am}$ and ${ }^{65} \mathrm{Zn}$ retained by Vibrio natriegens over time after resuspending the cells into sterile filtered, unlabeled seawater. Data are means $( \pm \mathrm{SE})$ of 3 replicates of Fe by Uronema sp. occurred rapidly and leveled off after $1 \mathrm{~h}$. At the end of the dietary uptake phase, the radioactivity associated with the ciliates had decreased slightly (to $52 \%$ ), indicating a release due to cycling of the metal. Upon ingestion of Vibrio natriegens, roughly $20 \%$ of the bacterially bound Zn was transferred to the ciliates, and approximately 20 to $25 \%$ of Am (Fig. 4). For Zn, uptake of desorbed metal may have accounted for up to $9 \%$, and for Am up to $8 \%$ (Fig. 4). The assimilation efficiencies of the 3 metals in Uronema sp. from ingested bacteria were about $79 \%$ for $\mathrm{Fe}, 29 \%$ for $\mathrm{Zn}$ and $24 \%$ for Am (Table 1). The mean concentration of each metal $\mu^{-3}$ of cell was determined for $V$. natriegens and Uronema sp. cells using the specific activity of each radioisotope. Concentrations in bacterial cells were 2 to 3 times those in the ciliates (Table 1).

At the end of the depuration period, a mean value of $75.4 \%$ of the Fe that the Uronema sp. had accumulated by feeding on Vibrio natriegens remained in or bound to the ciliates (Fig. 5), whereas only about $20 \%$ of the $\mathrm{Zn}$ and Am remained associated with the ciliates (Fig. 6). Depuration occurred in 2 phases; an initial phase characterized by a faster loss rate of the metal lasting about $1 \mathrm{~h}$, followed by a slower loss phase. Efflux rates $\left(\mathrm{d}^{-1}\right)$ of assimilated metals from Uronema sp. were only calculated for the second, slower loss phase and were 0.1 for Fe, 0.9 for $\mathrm{Zn}$ and 0.7 for Am (Table 1). Efflux rate constants were calculated for the slower (second) loss phase only as this phase represents metal loss due to metabolic activities.

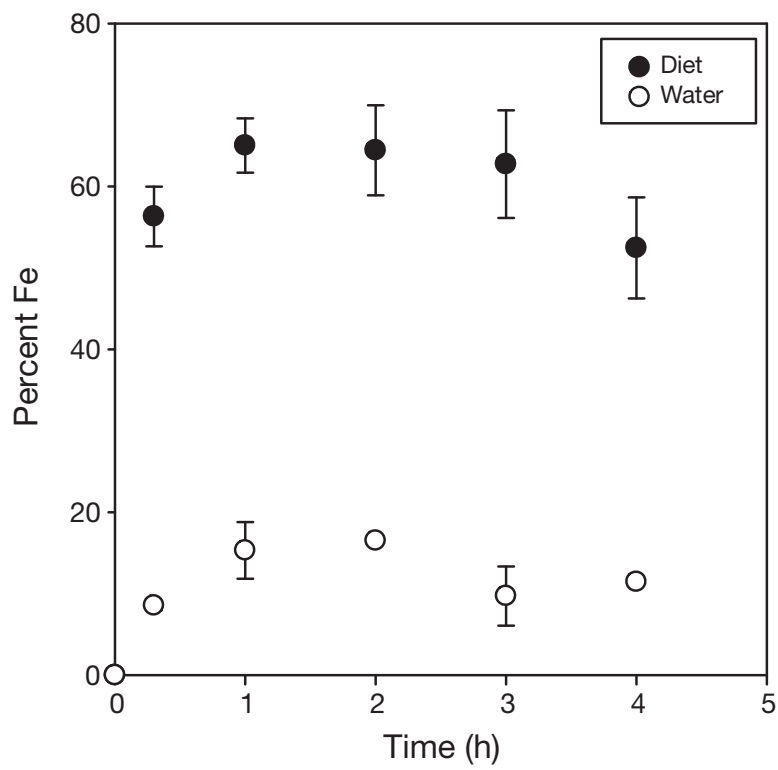

Fig. 3. Percentage of total ${ }^{55} \mathrm{Fe}$ in the culture associated with Uronema sp. over time while ingesting radiolabeled Vibrio natriegens (i.e. 'diet'), and accumulation of ${ }^{55} \mathrm{Fe}$ by Uronema sp. desorbed from $V$. natriegens cells (i.e. 'water'). Data are means $( \pm \mathrm{SE})$ of 3 replicates 


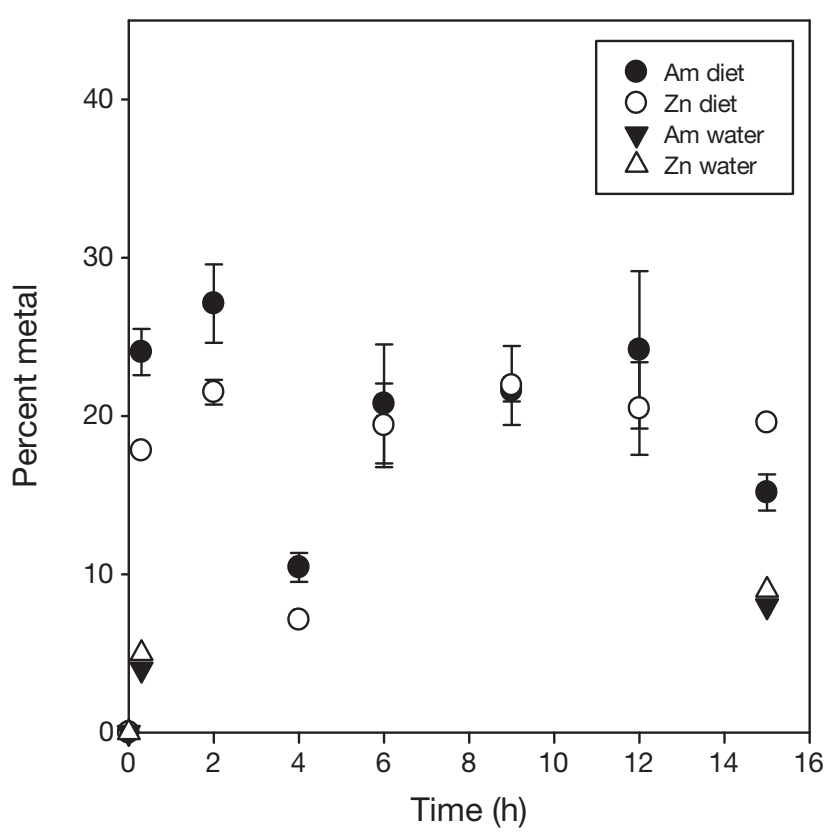

Fig. 4. Percentage of total ${ }^{241} \mathrm{Am}$ and ${ }^{65} \mathrm{Zn}$ in the culture associated with Uronema sp. over time while ingesting radiolabeled Vibrio natriegens (i.e. 'Am diet', 'Zn diet'), and accumulation of ${ }^{241} \mathrm{Am}$ and ${ }^{65} \mathrm{Zm}$ by Uronema sp. desorbed from $V$. natriegens cells (i.e. 'Am water', 'Zn water'). Data are means $( \pm \mathrm{SE})$ of 3 replicates for dietary uptake

\section{DISCUSSION}

Ciliated protozoa have been noted for their potential to be used as indicator organisms to assess the pollution of sediments and water in a variety of systems (Slabbing et al. 1990, Foissner 1999), including the monitoring of toxic effects of heavy metals in sewage sludge (Madoni et al. 1996, Martin-Gonzalez et al. 2005). In addition to their role as bioindicator organisms, ciliates are abundant and ubiquitous in benthic and pelagic environments where they can serve as a link between microbial loop organisms and animals in the metazoan food chain. Ciliates provide copepod predators with similar amounts of $\mathrm{C}$ as phytoplankton cells (Rieper 1985) and may even increase their egg hatching success (Heinle et al. 1977). They exhibit growth efficiencies of up to $40 \%$ when consuming bacterial cells (Ducklow 1983), indicating a relatively efficient transfer of energy and nutrients between the 2 trophic levels.

Uronema sp. can ingest about 700 bacterial cells $\mathrm{h}^{-1}$, and the process of digestion occurs within about $25 \mathrm{~min}$ (Sherr et al. 1988), which explains the sharp increase in the percentage of all 3 metals found associated with the ciliates within only $1 \mathrm{~h}$ of feeding on the radiolabeled Vibrio natriegens. The fluctuation of radioactivity in the ciliates between sample times during the dietary

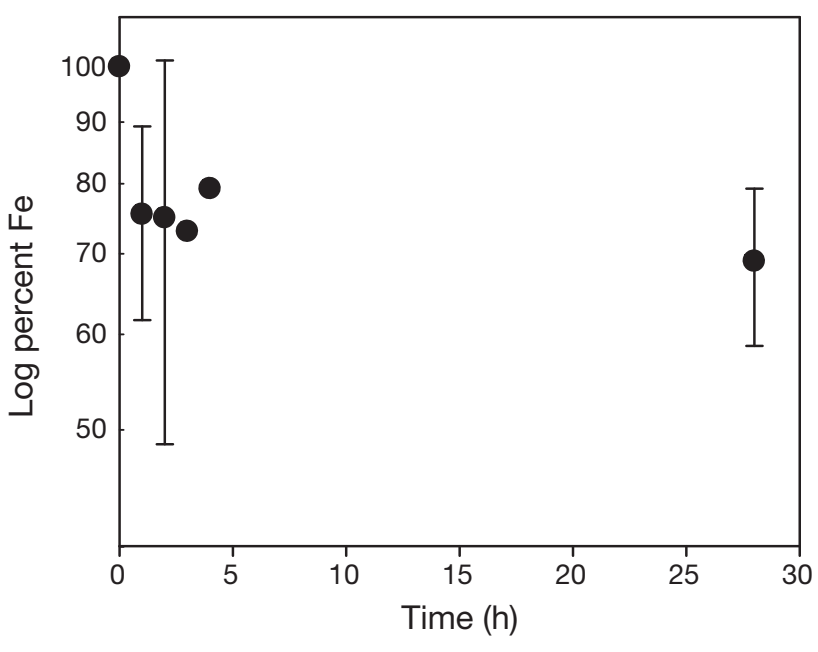

Fig. 5. Percentage of ${ }^{55} \mathrm{Fe}$ retained by Uronema sp. over time during the depuration period in unlabeled seawater. Data are means $( \pm \mathrm{SE})$ of 2 replicates

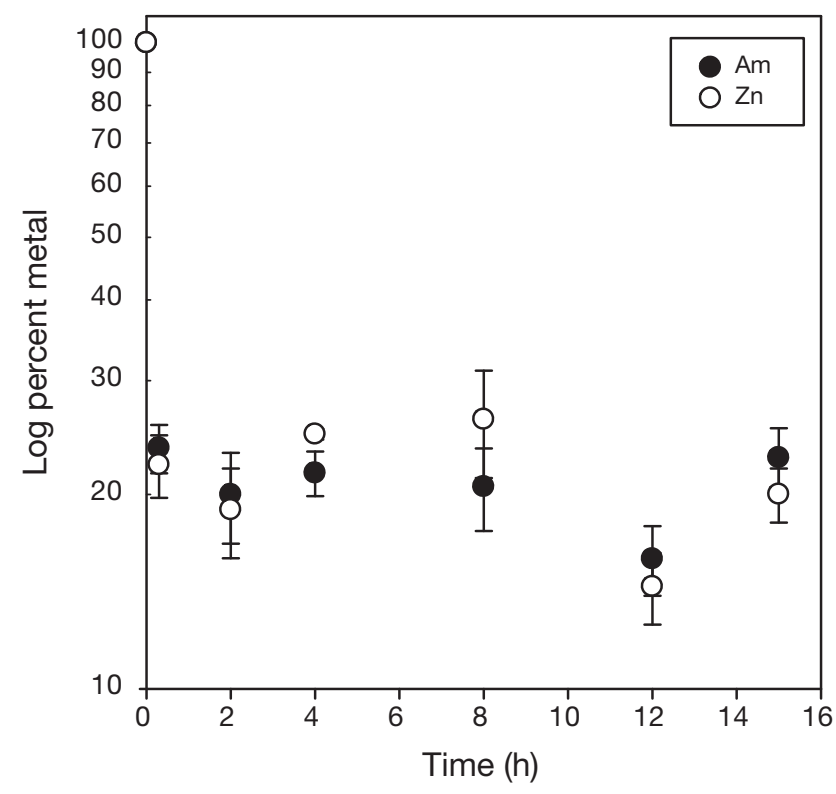

Fig. 6. Percentage of ${ }^{241} \mathrm{Am}$ and ${ }^{65} \mathrm{Zn}$ retained by Uronema sp. over time during the depuration period in unlabeled seawater. Data are means $( \pm \mathrm{SE})$ of 3 replicates

uptake (seen for Am and $\mathrm{Zn}$ ) can probably be attributed to cycling of these elements through the cells. Individual protozoan digestive vacuoles have a life span of 20 to $60 \mathrm{~min}$ from the time of formation to the point where their remaining contents are expelled (Fok et al. 1982). If ingestion and digestion occurs within such short timescales, then it can be expected that the ciliates in the present experiments were repeatedly ingesting bacterial cells and excreting waste products over the course of the dietary uptake phase. 
When assessing assimilation efficiencies in higher (multicellular) animals, gut passage time is often taken into account as a factor that can have an influence on this process (Wang \& Fisher 1999). This is based on the fact that organisms with longer gut passage times generally display high assimilation of contaminants due to the extended time period the digestive enzymes have to act on the food items (Sibly \& Calow 1986). Ciliates, on the other hand, produce food vacuoles in which prey items are contained and processed, a process that usually occurs on shorter timescales than it does for higher animals. The microenvironment of the food vacuoles is acidic compared with the ciliates' external environment. A pH range between 2 and 4 during active digestion (Howland 1928, Fok et al. 1982) may not only serve to kill ingested cells (Fok et al. 1982), but also create a tendency for metals to occur in soluble form (Millero 1998), and possibly to be transported into the ciliate cytoplasm rather than being egested or excreted. This is of interest especially for a metal such as Fe, which is not very soluble in seawater and readily forms colloidal precipitates or oxides that display reduced bioavailability for microorganisms (Rich \& Morel 1990). However, the acidity of the food vacuole leads to dissolution of this colloidal Fe and, therefore, an increase of its bioavailable form (Barbeau et al. 1996, Barbeau \& Moffett 1998). Once these complexes have dissolved, it is possible that the now soluble metal is transported across the vacuole membrane and into the cytoplasm of the cell leading to its accumulation inside the organism. It is possible that these conditions account, at least partially, for the high assimilation efficiency of $\mathrm{Fe}(79 \%)$ that was measured in the present study. In addition, Fe is mostly stored inside the cells, and therefore less likely to be excreted by the organisms. Since it is required as an enzyme cofactor for a variety of metabolic reactions, Fe should be retained by the cells rather efficiently as was illustrated by its low efflux rate from the ciliates.

The assimilation efficiency of Fe in the ciliates in the present study was higher than the 36 and $25 \%$ we calculated from Chase \& Price's (1997) study in the microflagellate Paraphysomonas imperforata under high and low Fe exposures, respectively. They found that 58 to $75 \%$ of the ingested Fe was excreted, whereas the ciliates in our study retained $75 \%$ of the $\mathrm{Fe}$ at the end of the depuration period. Chase \& Price (1997) also exposed their bacterial food to greater Fe concentrations than we used $(0.9 \mathrm{nM})$, i.e. $12.5 \mathrm{nM}$ (low Fe treatment) and $8.4 \mu \mathrm{M}$ (high Fe treatment). Thus, the flagellates in their study ingested substantially greater amounts of Fe than did the ciliates in our study and, together with physiological differences between the 2 protozoans, this may contribute to the differences between the 2 sets of assimilation efficiencies.
Of the 3 metals analyzed, Fe is also accumulated by heterotrophic marine bacteria to the greatest extent (volume concentration factor [VCF] of $1.5 \times 10^{6}$ in the present study). It can be assumed that at least $20 \%$ of the bioavailable Fe in surface ocean waters is bound to bacterial cells, and that the majority of it is located inside the cells (C. Vogel \& N. S. Fisher unpubl.). Given the high assimilation efficiency of Fe in Uronema sp. in the present study, a significant portion of the bacterially bound $\mathrm{Fe}$ is transferred to planktonic ciliates, which may in turn be consumed by zooplankton and then throughout the food web. The relatively low efflux rate of Fe from ciliates $\left(k_{\mathrm{e}}=0.1 \mathrm{~d}^{-1}\right)$ further strengthens the potential of Fe transfer to the next trophic level. Copepods have displayed an Fe assimilation efficiency of $32 \%$ when their food consists of ciliates (Twining \& Fisher 2004). The assimilation efficiency of Am in ciliates feeding on bacteria was the lowest of the 3 metals analyzed, as might be expected given that Am is a nonessential metal that mainly remains bound to cell surfaces (Fisher et al. 1983a). When bacteria are exposed to $\mathrm{Zn}$ over a range of ambient concentrations, less than half of the cellular $\mathrm{Zn}$ is transported into the cytoplasm (Keung et al. 2008), which is consistent with the assimilation efficiency observed for $\mathrm{Zn}$ in the ciliates.

We can compare the assimilation efficiencies of metals ingested by ciliates from bacteria to those in copepods feeding on ciliates and phytoplankton cells. Copepods feeding on ciliates assimilated about $32 \%$ of Fe and $77 \%$ of Zn (Twining \& Fisher 2004). Copepods feeding on log-phase diatoms assimilated about 5 to $16 \%$ of ingested Fe (Hutchins et al. 1995), $27 \%$ of $\mathrm{Zn}$ and $1 \%$ of Am (Reinfelder \& Fisher 1991). The observed assimilation of Fe is greater in ciliates than in copepods and may be due to physiological differences or requirements between protozoans and crustaceans. Differences in the $\mathrm{pH}$ of the digestive organs in ciliates and copepods may also account for these differences. Actively feeding copepods have a gut $\mathrm{pH}>7$ (Pond et al. 1995), which is significantly higher than that reported by Howland (1928) and Fok et al. (1982) for ciliate digestive vacuoles ( $\mathrm{pH} 2$ to 4 ). As noted above, the higher acidity of the ciliate vacuoles may explain the higher assimilation efficiency for Fe observed in ciliates than that seen in their predators.

While metals can be taken up by ciliates from the aqueous phase and from diet, our results indicate that the latter predominates. Thus, metals that are assimilated by a predator have the greatest potential to be transferred to the next higher trophic level. Generally, ingested material that is not assimilated is either egested in the form of discrete fecal pellets (e.g. in copepods), or excreted in dissolved form or egested as small amorphous particles, as is the case for ciliates 
(Elliott \& Clemmons 1966, Stoecker 1984). The fecal material produced by ciliates is not densely packaged and tends to break apart into fine particulate matter upon egestion (Elliott \& Clemmons 1966, Sieburth et al. 1978). Therefore, it is unlikely that metals incorporated in these small particles will enter the particulate flux of organic matter that sinks out of the photic zone, as is the case for copepod fecal pellets. Instead, metals not assimilated by ciliates are most probably recycled in surface waters where they, like excreted nutrients, and can become available again for accumulation by other planktonic organisms, including bacteria (Prast et al. 2007) and phytoplankton (Ota \& Taniguchi 2003). Finally, the lower concentration of metals observed in ciliates compared to that seen in their bacterial food is consistent with the general observation that most metals do not display biomagnification in marine food chains, methylmercury and cesium being notable exceptions (IAEA 2004, Mathews \& Fisher 2008).

Acknowledgements. This work was supported by National Science Foundation (NSF) OCE0527059 and NSF CHE0221934. We thank G. Taylor for providing bacterial cultures, A. Hartz for providing ciliates, and C. Mirasola for invaluable help conducting experiments. We also thank 3 anonymous reviewers for helpful comments on this manuscript.

\section{LITERATURE CITED}

Azam F, Fenchel T, Field JG, Gray JS, Meyer-Reil LA, Thingstad F (1983) The ecological role of water-column microbes in the sea. Mar Ecol Prog Ser 10:257-263

Barbeau KA, Moffett JW (1998) Dissolution of iron oxides by phagotrophic protists: using a novel method to quantify reaction rates. Environ Sci Technol 32:2969-2975

Barbeau K, Moffett JW, Caron DA, Croot PL, Erdner DL (1996) Role of protozoan grazing in relieving iron limitation of phytoplankton. Nature 380:61-64

Barbeau K, Kujawinski EB, Moffett JW (2001) Remineralization and recycling of iron, thorium and organic carbon by heterotrophic marine protists in culture. Aquat Microb Ecol 24:69-81

Beers JR, Stewart GL (1969) Micro-zooplankton and its abundance relative to larger zooplankton and other seston components. Mar Biol 4:182-189

Berk SG, Colwell RR (1981) Transfer of mercury through a marine microbial food web. J Exp Mar Biol Ecol 52: 157-172

Berk SG, Brownlee DC, Heinle DR, Kling HJ, Colwell RR (1977) Ciliates as a food source for marine planktonic copepods. Microb Ecol 4:27-40

Chase Z, Price NM (1997) Metabolic consequences of iron deficiency in heterotrophic marine protozoa. Limnol Oceanogr 42:1673-1684

> Cho BC, Azam F (1988) Major role of bacteria in biogeochemical fluxes in the ocean's interior. Nature 332:441-443

> Ducklow HW (1983) Production and fate of bacteria in the oceans. Bioscience 33:494-501

Elliott AM, Clemmons GL (1966) An ultrastructural study of ingestion and digestion in Tetrahymena pyriformis. J Protozool 13:311-323
Fenchel T (1986) The ecology of protozoa. Science Tech Publishers, Madison, WI

Fisher NS (1986) On the reactivity of metals for marine phytoplankton. Limnol Oceanogr 31:443-449

Fisher NS, Burns KA, Cherry RD, Heyraud M (1983a) Accumulation and cellular distribution of ${ }^{241} \mathrm{Am},{ }^{210} \mathrm{Po}$, and ${ }^{210} \mathrm{~Pb}$ in two marine algae. Mar Ecol Prog Ser 11: 233-237

Fisher NS, Bjerregaard P, Fowler SW (1983b) Interactions of marine plankton with transuranic elements. 1. Biokinetics of neptunium, plutonium, americium, and californium in phytoplankton. Limnol Oceanogr 28:432-447

Fisher NS, Bohe M, Teyssie JL (1984) Accumulation and toxicity of $\mathrm{Cd}, \mathrm{Zn}, \mathrm{Ag}$, and $\mathrm{Hg}$ in four marine phytoplankters. Mar Ecol Prog Ser 18:201-213

Fisher NS, Breslin VT, Levandowsky M (1995) Accumulation of silver and lead in estuarine microzooplankton. Mar Ecol Prog Ser 116:207-215

Foissner W (1999) Soil protozoa as bioindicators: pros and cons, methods, diversity, representative examples. Agric Ecosyst Environ 74:95-112

Fok AK, Lee Y, Allen RD (1982) The correlation of digestive vacuole $\mathrm{pH}$ and size with the digestive cycle in Paramecium caudatum. J Protozool 29:409-414

Fuhrman JA, Sleeter TD, Carlson CA, Proctor LM (1989) Dominance of bacterial biomass in the Sargasso Sea and its ecological implications. Mar Ecol Prog Ser 57:207-217

Gast V, Horstmann U (1983) N-remineralization of phytoplankton and bacterioplankton by the marine ciliate Euplotes vannus. Mar Ecol Prog Ser 13:55-60

> Heinle DR, Harris RP, Ustach JF, Flemer DA (1977) Detritus as food for estuarine copepods. Mar Biol 40:341-353

> Howland RB (1928) The pH of gastric vacuoles. Protoplasma $5: 127-134$

Hutchins DA, Wang WX, Fisher NS (1995) Copepod grazing and the biogeochemical fate of diatom iron. Limnol Oceanogr 40:989-994

IAEA (International Atomic Energy Agency) (2004) Sediment distribution coefficients and concentration factors for biota in the marine environment. International Atomic Energy Agency, Vienna

Johannes RE (1965) Influence of marine protozoa on nutrient regeneration. Limnol Oceanogr 10:434-442

Keung CF, Guo F, Qian PY, Wang WX (2008) Influences of metal-ligand complexes on the cadmium and zinc biokinetics in the marine bacterium, Bacillus firmus. Environ Toxicol Chem 27:131-137

- Lores EM, Snyder RA, Pennock JR (1999) The effect of humic acid on uptake/adsorption of copper by a marine bacterium and two marine ciliates. Chemosphere 38:293-310

Madoni P, Davoli D, Gorbi G, Vescovi L (1996) Toxic effect of heavy metals on the activated sludge protozoan community. Water Res 30:135-141

- Maranger R, Bird DF, Price NM (1998) Iron acquisition by photosynthetic marine phytoplankton from ingested bacteria. Nature 396:248-251

Martin-Gonzalez A, Borniquel S, Diaz S, Ortega R, Gutierrez JC (2005) Ultrastructural alterations in ciliated protozoa under heavy metal exposure. Cell Biol Int 29:119-126

Mathews T, Fisher NS (2008) Trophic transfer of seven trace metals in a four-step marine food chain. Mar Ecol Prog Ser 367:23-33

> Millero FJ (1998) Solubility of Fe(III) in seawater. Earth Planet Sci Lett 154:323-329

> Ota T, Taniguchi A (2003) Standing crop of planktonic ciliates in the East China Sea and their potential grazing impact and contribution to nutrient regeneration. Deep Sea Res II 50:423-442 
Pond DW, Harris RP, Brownlee C (1995) A microinjection technique using a $\mathrm{pH}$-sensitive dye to determine the gut $\mathrm{pH}$ of Calanus helgolandicus. Mar Biol 123:75-79

Porter KG, Sherr EB, Sherr BF, Pace M, Sanders RW (1985) Protozoa in planktonic food webs. J Protozool 32:409-415

Prast M, Bischoff AA, Waller U, Amann R, Berninger UG (2007) Effect of ciliates on nitrification and nitrifying bacteria in Baltic Sea sediments. Mar Ecol Prog Ser 350: 55-61

Reinfelder JR, Fisher NS (1991) The assimilation of elements ingested by marine copepods. Science 251:794-796

Reinfelder JR, Fisher NS (1994) The assimilation of elements ingested by marine planktonic bivalve larvae. Limnol Oceanogr 39:12-20

Rich HW, Morel FMM (1990) Availability of well-defined iron colloids to the marine diatom Thalassiosira weissflogii. Limnol Oceanogr 35:652-662

Rieper M (1985) Some lower food web organisms in the nutrition of marine harpacticoid copepods: an experimental study. Helgol Meersunters 39:357-366

Sherr EB, Sherr BF (1987) High rates of consumption of bacteria by pelagic ciliates. Nature 325:710-711

Sherr BF, Sherr EB, Rassoulzadegan F (1988) Rates of digestion of bacteria by marine phagotrophic protozoa: temperature dependence. Appl Environ Microbiol 54:1091-1095

Editorial responsibility: Peter Verity,

Savannah, Georgia, USA
Sherr B, Sherr E, Del Giorgio PA (2001) Enumeration of total and highly active bacteria. In: Paul JH (ed) Methods in microbiology, Vol 30. Academic Press, San Diego, CA, p 129-159

Sibly RM, Calow P (1986) Physiological ecology of animals: an evolutionary approach. Blackwell Scientific, Palo Alto, CA

Sieburth JM, Smetacek V, Lenz J (1978) Pelagic ecosystem structure: heterotrophic compartments of the plankton and their relationship to plankton size fractions. Limnol Oceanogr 23:1256-1263

> Slabbing ARD, Soria S, Burt GR, Cleary JJ (1990) Water quality bioassays in two Bermudan harbors using the ciliate Euplotes vannus, in relation to tributyltin distribution. J Exp Mar Biol Ecol 138:159-166

Stoecker DK (1984) Particle production by planktonic ciliates. Limnol Oceanogr 29:930-940

Tortell PD, Maldonado MT, Price NM (1996) The role of heterotrophic bacteria in iron-limited ocean ecosystems. Nature 383:330-332

Twining BS, Fisher NS (2004) Trophic transfer of trace metals from protozoa to mesozooplankton. Limnol Oceanogr 49: 28-39

Wang WX, Fisher NS (1999) Assimilation efficiencies of chemical contaminants in aquatic invertebrates: a synthesis. Environ Toxicol Chem 18:2034-2045

Submitted: December 16, 2008; Accepted: March 23, 2009

Proofs received from author(s): May 13, 2009 